\title{
Constructing a definition: Adolescent wellbeing from the perspective of the child and expert
}

\author{
Ellie K. Gennings · Hazel J. Brown · Denise Hewlett
}

\begin{abstract}
Background: Adolescent's wellbeing is gaining increasing attention, with it being part of the United Nations sustainable goals (United Nations, 2019 [online]). The question regarding what adolescent's wellbeing is, however, has received no rigorous answer (Alexandrova, 2017), even though it is regarded as a fundamental measure of learning and growing as a human being (Stevens \& Jarden, 2019). Understanding what wellbeing means to adolescents is vital and an under-researched area (Dunlop-Bennett et al., 2019) which has implications for the development and validation of tools to measure their wellbeing. Construct definition development literature highlights that experts, in addition to the relevant population, need to be consulted about the subject area to form a representative and valid definition (Podsakoff et al., 2016). Method: Two groups were invited to interview with the aim to understand their conspetulisations of wellbeing. Group 1 consisted of both expert practitioners and researchers from different disciplines in the field of wellbeing $(n=8)$ and Group 2 were young people aged 11-16 $(\mathrm{n}=41)$. Conclusion: Any definition needs to be reflective of the multi-faceted nature of wellbeing. Findings revealed three themes: holism, positive feelings, and external influences. Based on these findings a definition of wellbeing was formed. These conclusions should be used to underpin research with adolescents and the development of a measure of young people's wellbeing.
\end{abstract}

Keywords: Adolescent; expert; wellbeing; well-being; definition

\section{Introduction}

There are numerous descriptions of wellbeing within academic literature (Tabor \& Yull., 2018; Pouw \& McGregor., 2014; Dodge, Daly, Huyton \& Sanders, 2012; Diener, Lucas, Suh \& Smith, 1999) however, it is still cited by scholars that wellbeing is 'elusive' (Bharara, Duncan, Jarden \& Hinckson, 2019) and 'ill-defined' (Bourke \& Geldens, 2007). This may be due to the prevailing conclusion that wellbeing is broad and multidimensional (Hone, Schofield \& Jarden, 2015). Contributions to academic literature debating the definition and measurement of adolescent's wellbeing however remain frequent (Andresen, Bradshaw, \& Kosher, 2019; Bharara et al, 2019; Shoshani, 2019; Blaskova \& McLellan, 2018). These definitions and descriptions are often developed by adults for adults, developed by adults for adolescents or adolescents' conceptions are explored but no explicit definition is concluded (see Figure 1 below). Adolescents' perceptions are likely to differ from adults (Gillett-Swan, 2014) therefore findings from adult based research cannot be applied to adolescents (Bharara et al. 2019). Manning-Morton (2013), for example, reported that adolescent's wellbeing is influenced by spaces to be in and play in, childcare, parental leave, and quality of housing. This does not reflect adult's wellbeing as they

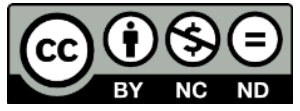

Copyright belongs to the author(s) www.internationaljournalofwellbeing.org 
are often not dependent on others for care, housing quality or spaces to play in due to their independence (Tabor \& Stockley, 2018). Understanding young people's conceptualisation of wellbeing is therefore worthy of investigation (Bharara et al., 2019).

\section{Figure 1. Suggested definitions of wellbeing}

\section{Defined within the general context}

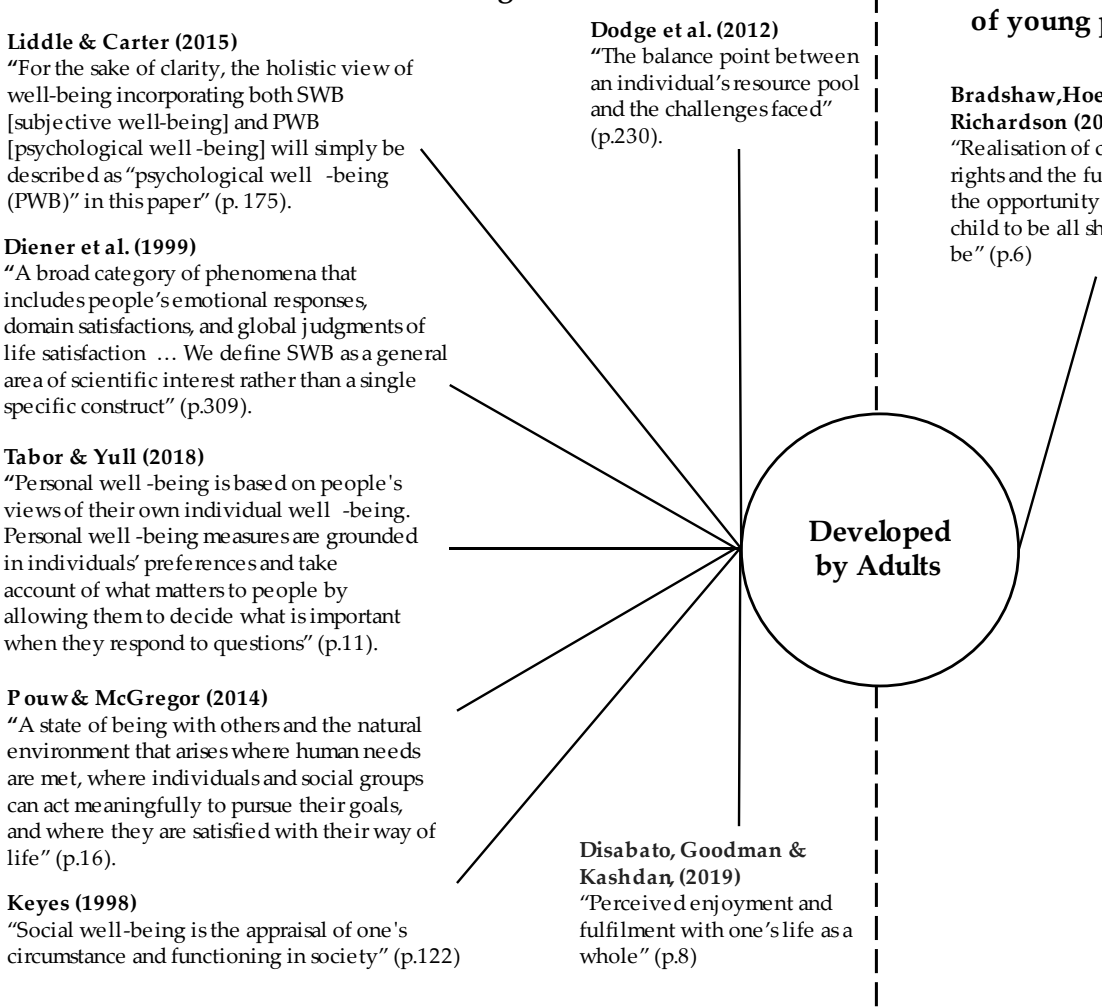

Defined within the context
of young people

Bradshaw,Hoelscher\& ison (2007)

tion of children's or he can

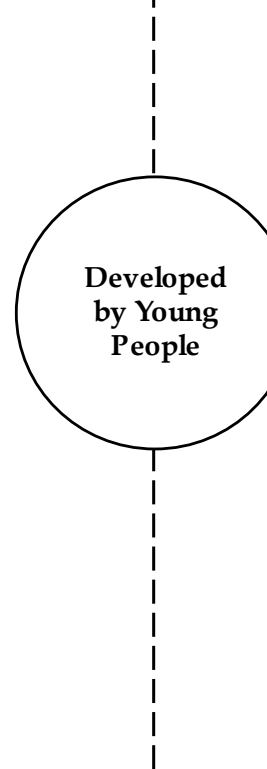

Explored within the context of young people, but not explicitly defined

Navarro et al. (2015) Explored views young people had regarding determinants of well -being

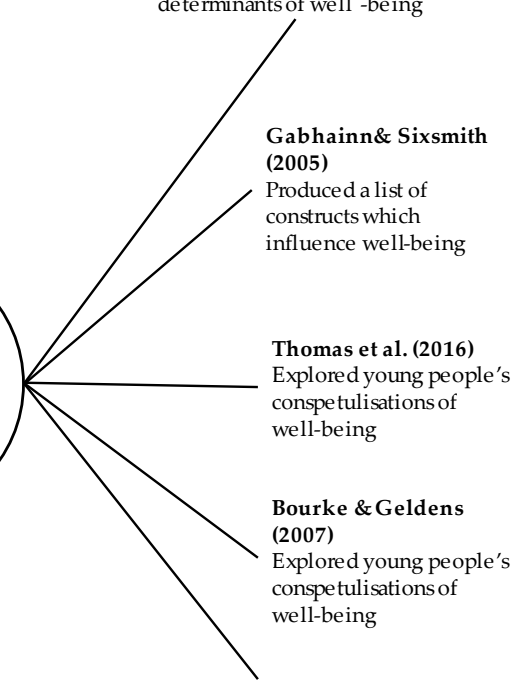

Gillett-Swan (2014) Explored young people's conspetulisations of well-being

It is imperative to be concerned with every individual's wellbeing for the benefit of society and not just for adults or vulnerable populations (McLellan \& Steward, 2015; Rees, Goswami \& Bradshaw., 2010). As mental health issues for young people increase (NHS Digital, 2018 [online]), so does interest in improving wellbeing, particularly when young people are considered (GillettSwan, 2014). It is subsequently important to understand what wellbeing means and therefore what is being improved (Bourke \& Geldens, 2007).

High quality relevant data about young people's lives can only be collected if they are involved (Bharara et al., 2019; Lundy, McEvoy \& Byrne, 2011). Lees et al. (2017) argues that young people have the right to have their views respected and thus they should be included in research. This is often not the case due to doubts in their maturity and literacy skills to participate meaningfully (Lundy et al., 2011). While adolescent's views should be included into research about them, Lundy, McEvoy and Byrne, (2011) suggest this is done in due weight and should not prevail on every issue. MacKenzie et al (2011) suggests consulting experts in addition to the relevant population when conceptualising a construct. Experts should therefore be consulted first and findings from this stage used to inform the inclusion of adolescents in research. Consulting experts first helps provide further understanding of data collected with young people, as expert's views enable insight and understanding into underlying responses from children (Lundy et al., 20011). When adolescents have been involved in conceptualising wellbeing, results are often descriptions or lists of what impacts their wellbeing (Thomas, Graham, Powell \& Fitzgerald 2016; Navarro et al., 2015; Gilett-Swan, 2014; Bourke \& Geldens, 
2007; Gabhainn \& Sixsmith, 2005). These are valuable contributions to the discussion of adolescent wellbeing however, to measure wellbeing reliably and validly, measures need to be underpinned by an explicit definition of wellbeing (MacKenzie, Podsakoff \& Podsakoff, 2011).

The purpose of this study is to conceptualise adolescent's wellbeing by consulting with experts in the subject area, from differing disciplines, and young people aged 11 to 16 . This is to encapsulate wellbeing's multidimensional nature and to support the development of a measure of wellbeing. Measures cannot be validated without an explicit definition of wellbeing; therefore, it is imperative a definition is derived from relevant research and underpinned by concept definition literature (Podsakoff, MacKenzie \& Podsakoff, 2016).

\section{Methodology}

\subsection{Participants}

Two groups of participants took part in the study $(n=49)$, Group 1 consisted of eight wellbeing experts $(4=$ Female, $4=$ Male $)$ and Group 2 consisted of 41 young people. All participants were residents of Great Britain. Group 1 was contacted directly and were only contacted if they had been working or researching in the field of wellbeing for $\geq 5$ years. Participants, in Group 1, were from a range of backgrounds including psychology, therapy, health geography, physiology, paediatrics, workplace wellbeing, social work and learning disability nursing, to gather a holistic understanding of wellbeing.

Group 2 were not contacted directly about participation but gatekeepers to this population were. The gatekeeper acted as an intermediary by passing on information about the study to parents and their children. Gatekeepers who had access to children aged 11-16 were identified and contacted, such as, school teachers and sports club organisers. Individuals who expressed interest in participation for Group 2 were only included if they were between the ages of 11 to 16 and were at secondary school. Participants came from 10 different secondary schools across the south coast of England. Table one summarises participant demographics.

Table 1. Group 2 Participant Demographics

\begin{tabular}{l|cc|ccccc} 
& \multirow{3}{*}{} & $\mathbf{M}$ & $\mathbf{F}$ & \multicolumn{5}{|c}{ School Year Group } \\
\cline { 4 - 8 } & & & $\mathbf{7}$ & $\mathbf{8}$ & $\mathbf{9}$ & $\mathbf{1 0}$ & $\mathbf{1 1}$ \\
\hline Total & 18 & 23 & 9 & 10 & 11 & 10 & 1
\end{tabular}

Note. Abbreviations: M (male), F (Female). UK school year group age breakdown: $7=11$ 12 years old; $8=12-13$ years old; $9=13-14$ years old; $10=14-15$ years old; $11=15-16$ years old.

\subsection{Protocol}

Institutional level ethical approval was gained and written informed consent was obtained from each participant before data was collected, including parents written informed consent for Group 2. The information sheet for adolescents obtained a Flesch Reading Ease Score of 64.6, which is considered standard and at secondary school level (Spadaro, Robinson \& Smith 1980).

\subsubsection{Group 1}

Participants in Group 1 were sent an invitation to interview via e-mail and an explanation as to why they had been invited. After expressions of interest the interviews were arranged. Interviews were conducted individually by the same researcher. Six of the interviews were conducted face to face, one via skype and one via a phone call. Participants were informed about 
the presence of a Dictaphone (Yamaha Pocketrak C24 Portable Recorder) used to record the interview which was then transcribed. The interviewer followed a semi structured interview guide to allow for flexibility with follow up questions (Bowling, 2014). A deductive approach was undertaken to develop the interview guide as it was informed by a review of literature which highlighted key discussion points including: the differentiation between wellbeing, happiness and life satisfaction; whether wellbeing is context specific and the significance of basic needs to achieve wellbeing.

\subsubsection{Group 2}

After the completion of analysis from Group 1's interviews, gatekeepers (including sports clubs and secondary schools) of the young people recruited in Group 2 received an email containing the information sheet and invitation for participation. Arrangements were made for the interviews via the gatekeeper. Participants also received the information sheet and consent forms that were subsequently signed by both them and their parent/guardian. Participation in the study was voluntary. A focus group style was chosen to provide an insight and narrative into the attitudes, perceptions and opinions of adolescents (Gibson, 2007), they were conducted in groups of three to four with a maximum of a two-year age gap between the oldest and youngest participant to help aid discussion (Gibson, 2007). Overall, 11 focus groups were conducted. The interview guide from Group 1 was adapted based on the analysis of results and used to inform the focus groups with young people.

The focus group was semi-structured and included one activity where participants, in pairs, had to rank 11 cards in order of importance to their wellbeing (see Figure 2). The content of the activity was derived from a review of literature. Each card was a determinant of wellbeing with items such as 'xbox' representing hedonic pleasure, 'having goals and challenges' representing eudaimonia and 'food and shelter' representing basic needs. The activity was designed to encourage discussion around topics prevalent within wellbeing literature. During the interview, participants split into groups of two and were given a set of 11 cards. They were asked to rank

Figure 2. Ranking cards

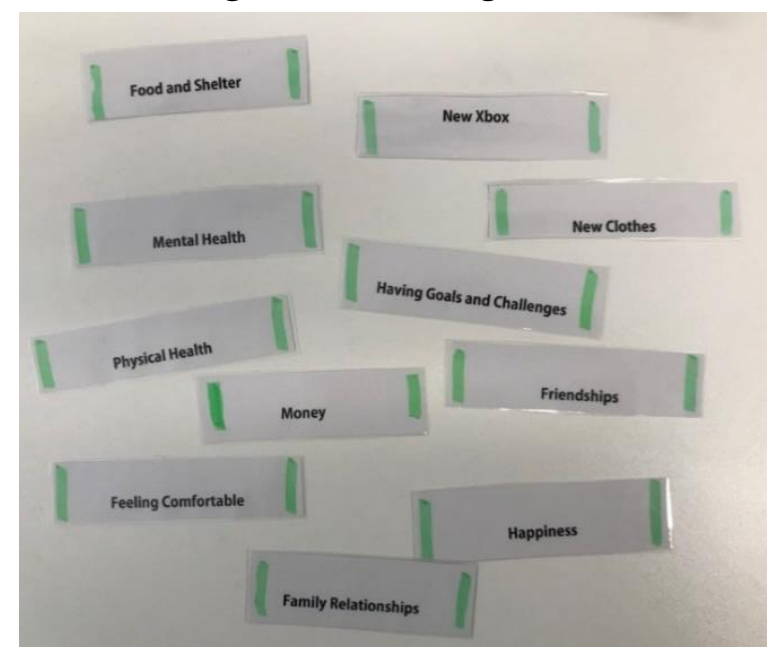

them in order of importance and once complete, they explained their order and why they decided to place cards higher and lower in the rank. Lundy et al (2011) suggests that a ranking activity is an age-appropriate exercise for adolescents which increases their engagement in research. Participants were also asked if they would add anything else to the list of cards which they 
perceived as important for their wellbeing. The purpose of the ranking activity was to understand if young people held the same importance over these topics as adults and to aid discussion.

\section{Data Analysis}

\subsection{Group 1}

Following each interview full transcripts were developed. Thematic analysis was used to identify themes within the data. Thematic analysis was chosen because it is flexible, has theoretical freedom and organises and describes a data set in rich detail (Maguire \& Delahunt, 2017). An inductive approach was taken so themes were strongly linked to the data. Braun and Clarke's (2006) six-phase framework for thematic analysis was used.

\subsection{Group 2}

The same data analysis process was conducted for Group 2's data including full transcriptions, thematic analysis and, although the final themes were the same, an inductive approach to developing coding and identifying first order themes was undertaken. Descriptive statistics were produced for the ranking data, identifying the average ranking position of each ranking card.

\subsection{Results - Expert's conceptualisations of wellbeing}

Results from Group 1 were organised into three themes: holism, positive feelings and external influences.

Wellbeing was conceptualised as multifaceted and these different facets are interconnected and impact each other, resulting in the theme 'holism'. It is often concluded within literature that wellbeing is a broad, multi-faceted and complex construct (Lijadi, 2018; Boyko, Coulton, Sabbagh-Gomez, Cooper, 2017; Dodge et al., 2012; Ryan and Deci., 2011 \& Spence, Powell, Self, 2011). This broad interpretation provides a rationale for an evidence-based definition of wellbeing to combat its ambiguity.

While discussing what contributes to wellbeing, participants discussed that it is an internal feeling which is linked to happiness and flourishing, leading to the conclusion that wellbeing is only concerned with positive feelings, hence the theme 'positive feelings'. Dodge et al. (2012) supports the notion that wellbeing is only concerned with positive affect as they argue that positive and negative affect are two separate dimensions. In addition, both Clarke et al (2011) and Tennant et al (2007) only included positively worded items in their measure of wellbeing showing that adolescents must also perceive wellbeing as a positive construct. Topics discussed within the theme 'positive feelings' were wellbeing's intrinsic nature, its close relationship to flourishing and the importance of how an individual perceives their heath and its influence on wellbeing.

The theme 'external influences' was developed as many external events were shown to influence an individual's wellbeing. These included the importance of having connections, absence of loneliness, the influence of life experience on values and priorities, the context in which we evaluate our wellbeing and the importance of obtaining basic needs. Table 2 (below) is a thematic diagram of results which show codes and first order themes.

\subsection{Results - Adolescent's conceptualisations of wellbeing}

The analysis for Group 2 resulted in the first order themes being organised into the same overarching themes as Group 1 entitled, holism, positive feelings, and external influences. 
Table 2. Thematic diagram of expert's conceptualisations of wellbeing

\begin{tabular}{|c|c|c|c|}
\hline Direct Quotes & Codes & $\begin{array}{l}\text { First Order } \\
\text { Themes }\end{array}$ & $\begin{array}{l}\text { Final } \\
\text { Themes }\end{array}$ \\
\hline $\begin{array}{l}\text { - Wellbeing is an overarching construct that encompasses a } \\
\text { number of different elements that matter in people's lives } \\
\text { - It is a vague concept that it is difficult to get a hand on }\end{array}$ & $\begin{array}{l}\text { Holistic } \\
\text { Broad } \\
\text { Multidimensional } \\
\text { Ambiguous }\end{array}$ & $\begin{array}{l}\text { Multi- } \\
\text { dimensional }\end{array}$ & Holism \\
\hline $\begin{array}{l}\text { - Feeling healthy within yourself and feeling at ease with your } \\
\text { own body and with your place in the world around you } \\
\text { - It is about someone being in charge and in control of their } \\
\text { own health }\end{array}$ & $\begin{array}{l}\text { Internal } \\
\text { Balance } \\
\text { Control } \\
\text { Individual }\end{array}$ & Intrinsic & \multirow{4}{*}{$\begin{array}{l}\text { Positive } \\
\text { Feelings }\end{array}$} \\
\hline $\begin{array}{l}\text { - Wellbeing to me is about someone really flourishing in life so } \\
\text { they are happy, they have good connections which may be to } \\
\text { family, friends, pets or connected in the community so they } \\
\text { are not isolated } \\
\text { - People who are in work generally report better wellbeing than } \\
\text { people out of work }\end{array}$ & $\begin{array}{l}\text { Flourishing } \\
\text { Purpose }\end{array}$ & \multirow{2}{*}{${ }^{*}$ Flourishing } & \\
\hline $\begin{array}{l}\text { - Huge number of the things that contribute to wellbeing, } \\
\text { contribute to happiness } \\
\text { Happiness is a kind of state which you attain every now and } \\
\text { then. You are happy. Whereas wellbeing is more of a kind of } \\
\text { constant state }\end{array}$ & $\begin{array}{l}\text { Hedonia } \\
\text { Happiness } \\
\text { Short-term } \\
\text { Emotion } \\
\text { Desires }\end{array}$ & & \\
\hline $\begin{array}{l}\text { - You could argue that someone might have a medical } \\
\text { diagnosis can have very high wellbeing } \\
\text { People with underlying health conditions can still experience } \\
\text { good wellbeing. People without them may not experience } \\
\text { good wellbeing. They are not cause and effect with each other }\end{array}$ & $\begin{array}{l}\text { Health } \\
\text { Evaluation } \\
\text { Control }\end{array}$ & Health & \\
\hline $\begin{array}{l}\text { - For me it is the absolute core that relationships, quality } \\
\text { relationships } \\
\text { - Isolation... just general connections and relationships, I think. } \\
\text { Having a sense of control in your life }\end{array}$ & $\begin{array}{l}\text { Connections } \\
\text { Social interaction } \\
\text { Isolation } \\
\text { Purpose }\end{array}$ & Connections & \multirow{5}{*}{$\begin{array}{l}\text { External } \\
\text { Influences }\end{array}$} \\
\hline $\begin{array}{l}\text { - I think it is relatively situation specific and so for both of those } \\
\text { reasons, wellbeing will necessarily change over time } \\
\text { - Some people who do not have a fixed abode, they are sofa } \\
\text { surfing and we may think their situation is extremely difficult } \\
\text { and how are they managing. But their wellbeing can be high, } \\
\text { they could have lots of satisfaction and gain from other things } \\
\text { in their life. }\end{array}$ & $\begin{array}{l}\text { Context } \\
\text { Situation Specific } \\
\text { Influence } \\
\text { Environment }\end{array}$ & Context & \\
\hline $\begin{array}{l}\text { - Every pound does not buy you an equal amount of happiness } \\
\text { indefinitely so there comes a point at which increases in } \\
\text { income don't actually buy you increases in happiness but at } \\
\text { the bottom it definitely makes a difference } \\
\text { - To the real basics of food and shelter, yes. I think it would be } \\
\text { difficult to achieve wellbeing without those }\end{array}$ & $\begin{array}{l}\text { Basic needs } \\
\text { Diet } \\
\text { Money } \\
\text { Health } \\
\text { Physical activity }\end{array}$ & Basic Needs & \\
\hline $\begin{array}{l}\text { - Things that make children feel good are probably going to be } \\
\text { different to things that make older people feel good and like } \\
\text { they are doing well } \\
\text { - I think there is as much less external [with old age], it is a } \\
\text { more internally defined thing...I have less bother about what } \\
\text { other people think regarding what I wear for example }\end{array}$ & $\begin{array}{l}\text { Development } \\
\text { Fluid with age } \\
\text { Priorities }\end{array}$ & \multirow{2}{*}{$\begin{array}{l}{ }^{*} \text { Life } \\
\text { Experience }\end{array}$} & \\
\hline $\begin{array}{l}\text { - Wellbeing is about the experience of what it is to feel good } \\
\text { with your life } \\
\text { It is about how we experience our lives overall but also about } \\
\text { the day to day and moment to moment moods and feelings } \\
\text { that we experience }\end{array}$ & $\begin{array}{l}\text { Experiential } \\
\text { Experience }\end{array}$ & & \\
\hline
\end{tabular}

Note. ${ }^{*}$ indicates themes which were predominantly different between the two groups. 
Wellbeing is perceived as multidimensional within the context of adults (Huppert \& So, 2013) and adolescents (Dunlop-Bennett, Bryant-Tokalau \& Dowell, Anthony, 2019). Wellbeing was also used interchangeably with other concepts, such as happiness and life satisfaction (Kelly, 2018; Bowling, 2017; Goodman, Disabato, Kashdan \& Kauffman, 2018; Dodge et al., 2012), because of its multidimensional nature. Findings from adolescent's support this, hence the theme 'holism'.

In line with Group 1, adolescents also identified that wellbeing is an internal, personal construct and physiological health is irrelevant but perception of one's own health is important to wellbeing. Adolescents also discussed how determination to set and achieve goals was important to their wellbeing. Having something to work towards and achieving made them feel good and enhanced their sense of wellbeing, resulting in the theme 'positive feelings'.

External influences, in alignment with academic literature (Alexandrova, 2017) and findings from Group 1, includes adolescents understanding that basic needs are important to enable survival however, excesses of money and material goods were agreed to have a limited, if not no, impact on wellbeing. Participants also discussed the importance of social interactions and both the physical and social family environment as this led to feelings of support and safety which contributed to their sense of wellbeing. Perceptions of others about them also influenced their sense of wellbeing as participants described being heavily influenced by their peers' judgements of themselves. Table 3 (below) shows a thematic diagram of finings and Figure 3 shows the reversed average ranking order of each card.

\section{Figure 3. Reversed average score for cards in ranking activity}

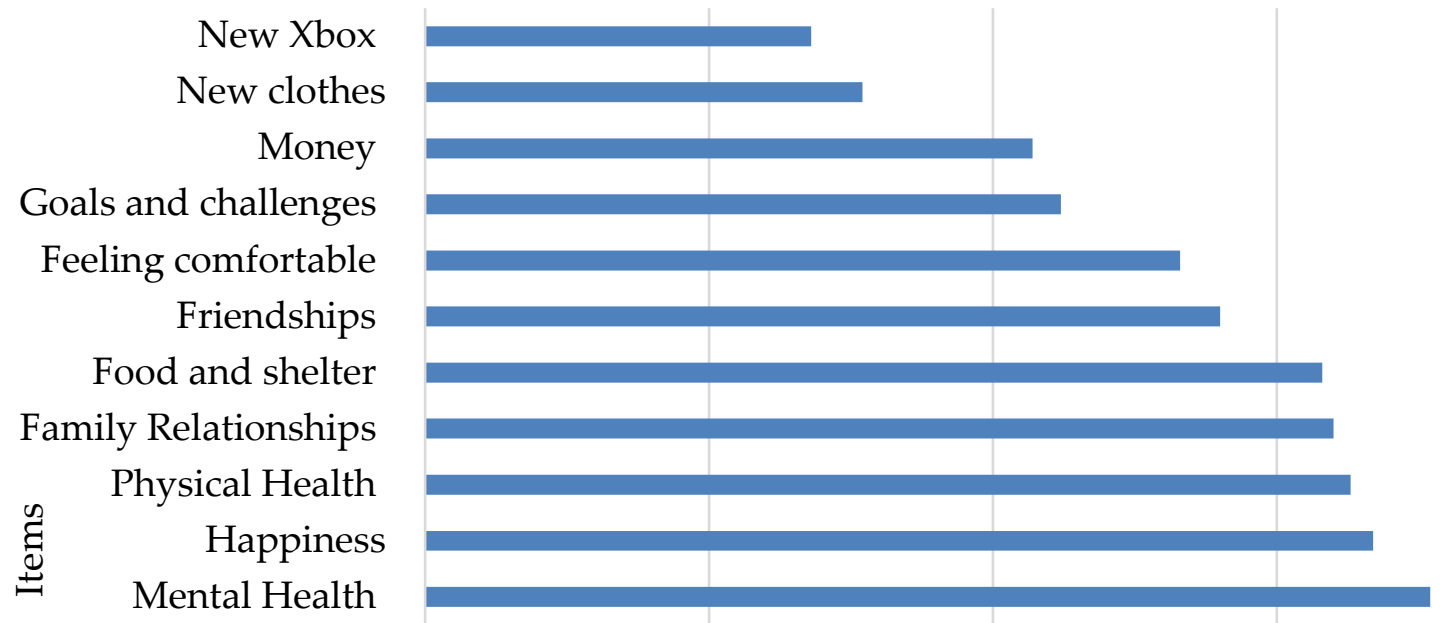

Reversed Average Rating

\section{Discussion}

There were four key differences identified through the thematic analysis of transcripts between the conceptualisations of adults and adolescents, supporting the need for a definition of wellbeing specific to young people. Young people highlighted the impact of other's judgments and the importance of family for their wellbeing and experts identified positive feelings beyond happiness and the influence of life experience on wellbeing. These four key differences will be discussed in the following sections. 
Table 3. Thematic diagram of adolescent's conceptualisations of wellbeing

\begin{tabular}{|c|c|c|c|}
\hline Direct Quotes & Codes & $\begin{array}{l}\text { First Order } \\
\text { Themes }\end{array}$ & $\begin{array}{l}\text { Final } \\
\text { Themes }\end{array}$ \\
\hline $\begin{array}{l}\text { - Physical health, food and shelter and happiness... they } \\
\text { kind of all just link together in the way that like when you } \\
\text { do exercise it makes you feel happy } \\
\text { - I think it is like the main thing you should focus on... you } \\
\text { can't have one without the other. You can't have good } \\
\text { physical health without good mental health or good } \\
\text { mental health without good physical health }\end{array}$ & $\begin{array}{l}\text { Interaction between } \\
\text { Influences on } \\
\text { Wellbeing }\end{array}$ & Interlinked & \multirow[t]{2}{*}{ Holism } \\
\hline $\begin{array}{l}\text { - You've got like your overall wellbeing but then you have } \\
\text { like... if you break it down you have the wellbeing that } \\
\text { you would have at school like during lessons and in } \\
\text { break and kind of like then the wellbeing you have at } \\
\text { athletics like how you're training how you feel and like } \\
\text { how it is going? }\end{array}$ & Happiness & $\begin{array}{l}\text { Inter- } \\
\text { changeable }\end{array}$ & \\
\hline $\begin{array}{l}\text { - Wellbeing is kind of how you're feeling and what you feel } \\
\text { is very personal to you } \\
\text { - } \quad \text { It is different to every single person }\end{array}$ & $\begin{array}{l}\text { Unique } \\
\text { Individual }\end{array}$ & Personal & \multirow{3}{*}{$\begin{array}{l}\text { Positive } \\
\text { Feelings }\end{array}$} \\
\hline $\begin{array}{l}\text { - If you aren't physically healthy, you won't feel good } \\
\text { - Making sure you're ok whether that is physically or } \\
\text { mentally }\end{array}$ & $\begin{array}{l}\text { Feeling Ok } \\
\text { Physical Health } \\
\text { Mental Health } \\
\text { Mind Set } \\
\text { Happiness } \\
\text { Care }\end{array}$ & Health & \\
\hline $\begin{array}{l}\text { - Having a set target for you to achieve is good because it } \\
\text { gives you a fixed mindset on what you want } \\
\text { - I think it helps with your motivation to get things done }\end{array}$ & $\begin{array}{l}\text { Purpose } \\
\text { Goals } \\
\text { Focus of Attention } \\
\text { Motivation to Achieve }\end{array}$ & $\begin{array}{l}\text { Deter- } \\
\text { mination }\end{array}$ & \\
\hline $\begin{array}{l}\text { - Family relations and friendships anyone needs because } \\
\text { otherwise you would feel a bit lonely } \\
\text { If you have good relationships with your parents and that } \\
\text { they could improve your happiness as you can always } \\
\text { talk to them about stuff. }\end{array}$ & $\begin{array}{l}\text { Loneliness } \\
\text { Mood lifting } \\
\text { Hobbies } \\
\text { Connections } \\
\text { Interactions } \\
\text { Other's state } \\
\end{array}$ & $\begin{array}{l}\text { Social } \\
\text { Interactions }\end{array}$ & \multirow{4}{*}{$\begin{array}{l}\text { External } \\
\text { Influences }\end{array}$} \\
\hline $\begin{array}{l}\text { - It doesn't matter if you don't have any dads or you have } \\
\text { two. You still need family relationships and friendships } \\
\text { and happiness to truly thrive to any extent } \\
\text { I also think the environment of where you are also helps } \\
\text { coz like quite a degrading place would give you bad } \\
\text { wellbeing because it could promote bad actions and bad } \\
\text { wellbeing. Say somewhere is full of happy people and in } \\
\text { an all-round good place could kind of make you live better } \\
\text { and have a good wellbeing }\end{array}$ & $\begin{array}{l}\text { Family Set up } \\
\text { Permanent } \\
\text { Comfort } \\
\text { Encouragement } \\
\text { Parents } \\
\text { Home environment } \\
\text { Physical home } \\
\text { Siblings }\end{array}$ & $\begin{array}{l}\text { *Upbringing } \\
\& \text { Parental } \\
\text { Dependence }\end{array}$ & \\
\hline $\begin{array}{l}\text { - When you're at school you could have like an anxiety } \\
\text { because you think people will judge you if you get } \\
\text { something wrong in class or if you aren't the best at sports, } \\
\text { people better than you will judge you or not want you on } \\
\text { their team so } \\
\text { It depends on how serious the situation is really... It could } \\
\text { be something that sticks with you and then you could } \\
\text { think 'oh am I really this?' or whatever and then it just like } \\
\text { puts you down }\end{array}$ & $\begin{array}{l}\text { Self Confidence } \\
\text { Self-Acceptance } \\
\text { Mind Set } \\
\text { Judgement } \\
\text { Being Yourself } \\
\text { Fitting in } \\
\text { Social Media } \\
\text { Opinions }\end{array}$ & $\begin{array}{l}{ }^{*} \text { Fitting in \& } \\
\text { Judgement }\end{array}$ & \\
\hline $\begin{array}{l}\text { - Like an Xbox you don't really need it but you can have it } \\
\text { just for like, to be a nice thing when you're sad maybe } \\
\text { I don't think you need loads of money but just some to } \\
\text { support you and that }\end{array}$ & $\begin{array}{l}\text { Nice } \\
\text { Can be Essential } \\
\text { Limited Effect }\end{array}$ & $\begin{array}{l}\text { Material } \\
\text { Goods }\end{array}$ & \\
\hline
\end{tabular}

Note. ${ }^{*}$ indicates themes which were predominantly different between the two groups. 


\subsection{Self-acceptance and judgement}

Adolescent's wellbeing was greatly influenced by acceptance of others and having resilience to cope with judgements placed on them. Participants frequently identified that having selfconfidence and being resilient was an important determinant of wellbeing; 'being mentally resilient and I guess not listening to people who think that they can like tell you bad stuff'. It could be suggested that many of them lacked self-resilience as they often discussed the impact of other people's opinions about them;

When you're at school you could have like an anxiety because you think people will judge you if you get something wrong in class or if you aren't the best at sports, people better than you will judge you or not want you on their team

At school you try and put a brave face on for everyone at times but at home it is different and no one is there to watch you

Adults appeared less self-conscious of other's opinions and judgements of themselves. One expert commented;

I have a different perspective on how I think about it [wellbeing] compared to how I did.... I have less bother about what other people think regarding what I wear for example. I remember when my kids had to have seen the right thing before they talked to their friends at school. So, for them to feel ok they need to be accepted by peers, fitting in and all of that is much, much stronger. When you're older there is a little more about life on my terms

Fear of judgment by others is not apparent in models of wellbeing such as Ryff's six-factor model of wellbeing (Ryff \& Keyes, 1995) and PERMA (Seligman, 2004), or discussed in its underpinning theory. This suggests that young people have a different understanding of the concept wellbeing in comparison to adults. Children place value on friendships to fulfil needs of belonging, to feel capable, respected and accepted (Foley et al., 2012). One expert described adults as 'selfcontained' and highlighted that this is the biggest difference between adults and children, who are more dependent on others due to their life experience. Foley and colleagues (2012) interviewed children with disabilities about their perceptions of wellbeing, it was concluded that their sample perceived friends who did not support a feeling of acceptance and belonging were 'barriers to a good life' (p.328). It was also evident within this study that acceptance from peers was important for young people to feel comfortable, 'if people accept you for being you then you are more likely to be more comfortable'. This evidence provides support for having a specific definition of young people's wellbeing.

\subsection{The impact of family}

Young people frequently discussed the importance of their parents in making them feel well. As the ranking data suggests, family relationships are more important than friendships. This was explained in interviews through the loyalty's participants had to their family and the permanent nature of family. Dunlop-Bennett et al. (2019) also found that Samoan children valued 'spending time with family' and 'having family around' more than 'hanging out with friends' (p.109). Furthermore, 'spending time with family' was the only thing identified by their entire sample, highlighting its importance. The ranking data (Figure 3 above) shows that, on average, young people ranked family relationships fourth out of the 11 cards regarding its importance to achieving a good level of wellbeing. Family relationships were regarded as important, but not as important as other constructs like mental health. An explanation for the difference in value could be due to the age difference in samples (8 years old vs 11-16 years old), and the younger children in Dunlop-Bennett and colleagues (2019) research being more dependent on their family. Bharara 
et al. (2019) studied a similar age group and explored New Zealanders' (aged 11-13-years) conspetulisations of wellbeing and identified similar findings whereby $60 \%$ of their sample valued family relationships in relation to their wellbeing needs.

Adult's did not discuss the role of parents regarding wellbeing. As individuals mature, they become less dependent, meaning reliance on others, such as parents, lessens. One expert however, highlighted the importance of home. Good quality housing provides comfort, safety and a feeling of connection to the community which, Maslow considers as the one of the most important biological and physiological needs as it is part of the first level in his model (Maslow, 1943). Feelings of comfort, safety and connection were attributed to parents, not housing, by young people.

\subsection{Feelings beyond happiness}

Adults were able to identify positive feelings beyond happiness such as flourishing, and the importance of that to wellbeing. Bowling (2017) states that there is ongoing confusion and overlap between similar constructs to wellbeing, like happiness and flourishing, which few authors distinguish between. Group 1 discussed the term flourishing in relation to wellbeing;

Wellbeing to me is about someone really flourishing in life

We think of wellbeing as being about flourishing and doing well across all the different aspects of your life

This supports Smith and Reid (2017), Goodman et al. (2018), Humberstone (2015), McLellan and Steward (2015), Dodge et al. (2012) and Ryan and Deci (2001) who have also discussed the term flourishing in relation to wellbeing. Dodge et al. (2012) stated that it is a synonym of positive psychology. Flourishing was described by one expert as;

I think flourishing is about happiness, contentment and agency. Of course, for different people it will mean different things. For different people, flourishing will relate to stability, financial stability and employment stability and those sorts of things but I wouldn't want to constrain it too much because some people don't desire that stability and absolutely flourish in their lives without

Between 1938 and 2000, there have been 39 varying definitions of flourishing (Dodge et al., 2012), highlighting its complexity. Young people may not have the emotional literacy to identify what it feels like to flourish. Although, during focus groups they did describe determination and scenarios which could be labelled as flourishing, for example;

Having something to look towards and sometimes people, who struggle with their wellbeing or mental health is because they cannot see the clear path and having that can just guide you in some way

Having a set target for you to achieve is good because it gives you a fixed mindset on what you want

Having goals because that can make you happy when you achieve them

These comments allude to the young people wanting to have a purpose in life and achievement of their purpose being linked to feeling good. Having purpose and feeling good when achieving something are qualities of flourishing. Lijadi (2018) and McLellan and Steward (2015) discuss the positive influence of education on flourishing. The opportunity for, and quality of, different experiences, like education, can range across cultures, location, and economic status. These experiences are needed though to stimulate positive feelings which ultimately influence 
wellbeing. Huppert and So (2013) concluded that features of flourishing included meaning, selfesteem and optimism, which are all identifiable factors in the quotations.

\subsection{Life experience}

Experts identified that, with age, the experiences and values an individual has are likely to change. An example of differences in priorities may be young people valuing friendships, adults valuing their career path and elderly individuals valuing their health. Each individual would gain satisfaction from achieving their priority which ultimately influences the level of wellbeing they have. Young people did not discuss how age can change priorities or how age can impact their conceptualisations of wellbeing. One expert, while reflecting on their own life and commented on what gave them a good sense of wellbeing;

If I think about my own personal experience, ten years ago I was wanting to go out with friends, and the Christmas rota... I used to be horrified at the thought of working on New Year and I'd rather work Christmas so I could have New Year off so I could go out with friends and socialise. Now, I'd quite happily stay in New Year and spend Christmas with my nana and my mum

This is a real-life example of an individual's values and priorities changing as they get older. Age is linked to life experiences, social norms, and priorities because they change as age increases. Age itself does not influence wellbeing but the changes in experiences, social norms and priorities do. Age is the agent for this change. This links to Blanchflower and Oswald's (2008) work as they presented wellbeing as a U-shape over a life cycle. Their explanation for this is that mental distress reaches a maximum in middle age as happiness and life satisfaction are decreased (Blanchflower \& Oswald, 2008). These two factors are portrayed by Blanchflower and Oswald (2008) as constructs which have greatest influence on wellbeing, although wellbeing has not been clearly defined within the article. Blanchflower and Oswald's (2008) conclusions could explain why there is wealth of research around adult's wellbeing and several measures of wellbeing which focus on the adult population, not on the younger population. This finding supports the rationale of this paper, arguing that there is need for a definition of young people's wellbeing, developed by young people.

\section{Common discussion points}

The following sections discuss topics which both experts and adolescent identified as influencing factors on wellbeing. Topics fit within the two broad themes positive feelings and external influences.

\subsection{Positive feelings and their impact on wellbeing}

\subsubsection{Internal nature of wellbeing}

Wellbeing was conceptualised by experts as a personal feeling, 'Feeling healthy within yourself and feeling at ease with your own body and with your place in the world around you'. It is described as something individuals have ownership of, and this feeling of control contributes to a greater sense of wellbeing, supporting the notion that wellbeing is subjective (Pouw \& McGregor, 2014; Dodge et al., 2012; Waterman et al., 2010). Adolescent's identified that wellbeing is also personal and unique to everyone, 'I guess you're just yourself... It is different to every single person'. Individual differences are something prevalent throughout wellbeing literature (Pouw \& McGregor, 2014). The definition of wellbeing therefore must allow for the notion that 
specific influences on wellbeing will be unique to everyone. Stevens and Jarden (2019) state that wellbeing has core similarities between individuals. One adolescent stated;

Even if, I prefer listening to one genre of music to my friend, we still both ultimately listen to music... Even if I have one method of dealing with it, the needs are ultimately come down to the same thing

This supports Stevens and Jarden (2019) as it shows that although influences on wellbeing are unique to individuals, there are core similarities between people, providing support that the definition of wellbeing needs to be all encompassing. Moreover, Bharara et al. (2019) applied a prototype analysis to their exploration of adolescent's wellbeing. A prototype analysis assumes that some components are more central and important to a concept, and others are considered peripheral as they are still important, but less so than the central (Rosch, 1975). This reinforces Stevens and Jarden's (2019) conclusion that wellbeing has core similarities, but it allows for individual differences whereby some components and of determinants of wellbeing are more important to some individuals.

\subsubsection{Physical health, mental health and wellbeing}

Feeling healthy was considered important for wellbeing for both adolescents and experts. The word 'health' to adolescents meant a mixture of physical health, mental health and feeling generally ok, which Table 3 (above) shows. Although feeling good was deemed beneficial for wellbeing, one adolescent commented 'you could be severely disabled but as long as you're mentally healthy it can help you get through' which highlights that good mental health is more important for wellbeing than good physical health. Experts often referred to an individual's evaluation of their health, not their actual health. Control was an important aspect when evaluating one's own health;

It is about someone being in charge and in control of their own health... someone can have a diagnosis of mental or physical [ill-] health but still have really high and thriving wellbeing compared to someone with no diagnosis but very low wellbeing

This was a common discussion point within both groups interviews which is linked to mindset. The argument that anyone can have a high level of wellbeing no matter what their health condition is, is supported by Tudor's (1996) Dual-Continuum Model of Mental Health seen in Figure 4 (below). This also highlights that individuals with perfect health can have poor wellbeing.

Figure 4 (below) reiterates the point that wellbeing is not concerned with individual's actual health, but their own internal evaluation and perception of their health. The value of healthperception over physical health was also evident in the ranking activity, where mental health was given, on average, the highest-ranking position, in comparison with all other cards. Physical health ranked on average third overall (see Figure 3 above). Specific interventions to improve health like mindfulness were not discussed by adolescents, even though there is evidence to suggest mindfulness can improve adolescent's wellbeing (Sanger, Thierry, Dorjee, 2019). Bharara et al. (2019) suggests that young people are uninformed about such interventions and have a greater understanding of more visible pathways to enhance wellbeing. Findings showed that visible pathways such as family, friends and hobbies were often linked to improving mental and physical health, supporting Bharara et al. (2019). 
Figure 4. The dual-continuum model of mental health (Tudor, 1996: Adapted)

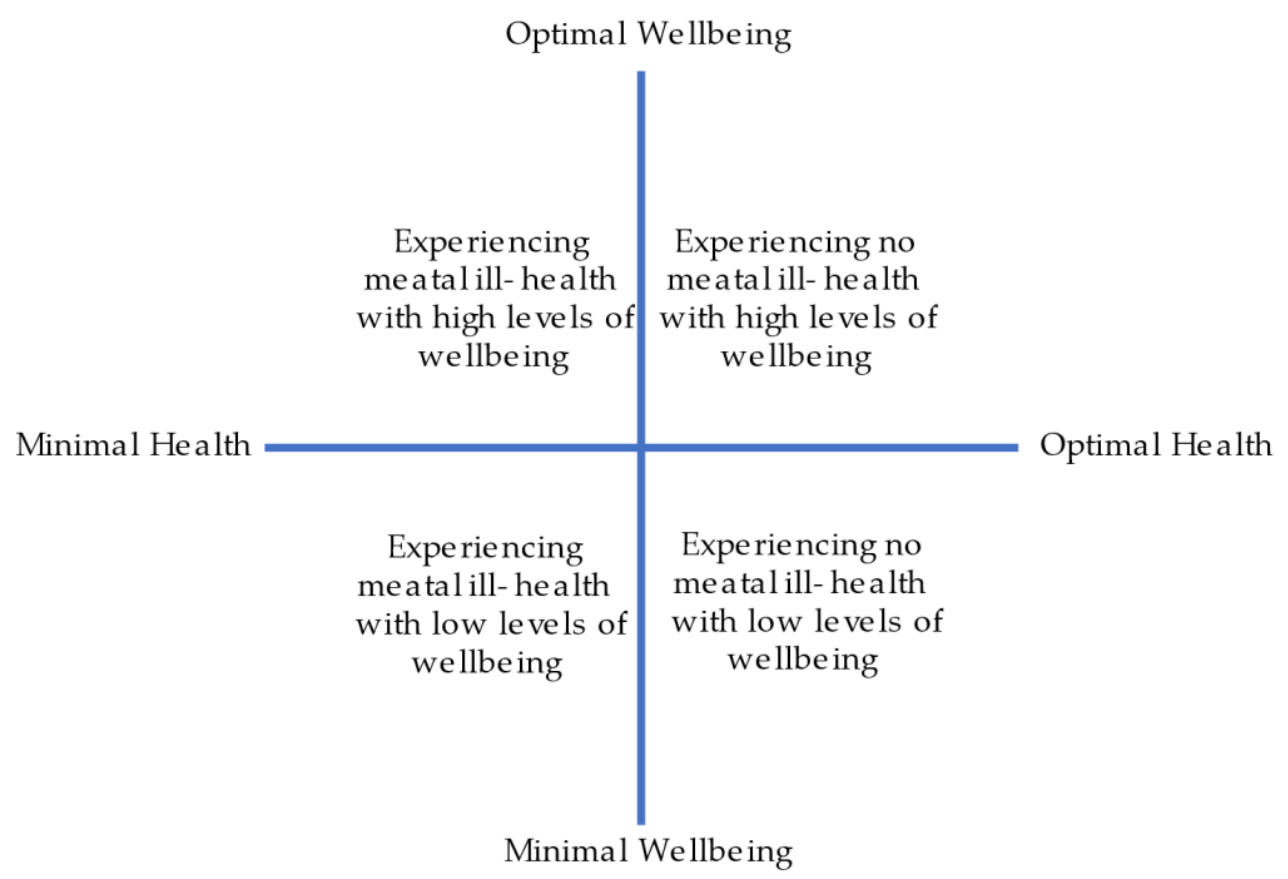

\subsubsection{Determination to achieve}

Although determination could be linked to flourishing, adolescents described goal setting as the tool which made them feel determined. Flourishing for experts was about having purpose and feeling good when achieving. Determination resulted in young people having a focus and being motivated to achieve:

If you don't have anything to kind of like, lead you forward then I guess um... it gives you something to work towards... I think it helps with your motivation to get things done.

Goal setting is theoretically underpinned by motivation and one of its purposes is to direct attention (Lunenburg, 2011). Having a goal to achieve links to feeling a sense of purpose which is central to a eudaimonic philosophy (Boyko et al., 2017; Waterman et al., 2010). This is also reflected in Selgiman's (2004) PERMA model of wellbeing as the 'A' stands for 'Achievement', where having optimism to achieve, and achievement itself is considered a key determinant of good wellbeing. Although having goals to generate individual's determination is important to wellbeing, the results from the ranking activity showed that on average goals and challenges were not ranked highly by adolescents, as they were ranked overall as eighth (see Figure 3 above).

\subsection{External influences and their impact on wellbeing}

\subsubsection{Connections to others}

Relationships with others is a prevalent topic in wellbeing literature, where its influence on wellbeing is acknowledged (Foley et al., 2012; Putnam, 2001; Ryan \& Deci, 2001). Adolescents felt being around others who were considered friends or family as important for wellbeing. Experts stated that connections are imperative for wellbeing because humans need to feel loved and cared for. This finding is supported by Maslow's (1943) hierarchy of needs as the third level in this model is 'belongingness and love needs'. This level includes social connections and 
relationships as a basic need which contributes to self-actualisation. Ryan and Deci (2001) included relationships as a basic need for all humans and Seligman (2012, P.20) also comments;

When was the last time you laughed uproariously? The last time you felt indescribable joy?

The last time you sensed a profound meaning and purpose? The last time you felt enormously

proud of an accomplishment? Even without knowing the particulars of these highpoints in

your life, I know their form: all of them took place with other people

This statement implies that humans rely on connections with others to feel many different positive emotions. Without these connections, individuals can feel isolated. Literature about isolation and loneliness shows that it has a large association with negative mental and physical health (Courtin \& Knapp, 2017), which has been shown in literature to be detrimental for wellbeing (Courtin \& Knapp, 2017).

Adolescents highlighted that happiness can be transmitted from one individual to another; 'If someone else is in a bad state of mind it can sometimes rub off on other people'. Simply being around positive people is seen to be beneficial for wellbeing due to the influence of others' mood on one's self and vice versa (Povey, 2015). This finding is supported by Bharara et al. (2019) who found that more than half of their sample valued positive friendships and family relationships as enhancers of wellbeing. Social interactions are part of wellbeing models like PERMA (Seligman, 2004) and the United Kingdom's 5-ways to wellbeing (Government Office for Science, 2008 [online]).

Hobbies were also discussed by adolescents as they provided the opportunity for young people to socially interact with others, have purpose and provided a distraction. The examples of hobbies discussed were sports, train spotting, drama and music (see Table 3 above). Feeling a sense of purpose within a eudaimonic philosophy greatly contributes to a feeling of wellbeing (Deci \& Ryan, 2008). Sport featured most and was often linked to the physical and psychological health benefits of participation and being outside but, more importantly the social interaction it promoted. Mata et al. (2012) has shown young people gain a sense of belonging from being part of clubs at school which contributes to them having purpose (Lijadi, 2018; McLellan \& Steward, 2015). Sport clubs had a bigger impact on sense of belonging than academic, music, creative, language and agricultural clubs. These findings were linked to suicide rates and Mata et al. (2012) concluded that extracurricular activities make a good intervention to decrease adolescent suicide risk.

\subsubsection{Context and wellbeing}

Experts conceptualised wellbeing as being context specific and adolescents referred to context by detailing how different environments, such as school and sports clubs, can impact overall wellbeing. Kelly (2018) also argues that wellbeing is contextual to the status of a population or an individual regarding illness and what strategies these individuals or populations have for maintaining good physical, psychological and spiritual wellness. Headey and Wearing (1992) however conclude that wellbeing is 'fairly stable'. In addition, a eudaimonic philosophy states that wellbeing is developed over time with personal growth and development (Boyko et al., 2017; Waterman et al., 2010). This suggests that it is mood which changes in context, not wellbeing. In support, Alexandrova, (2017) argues that wellbeing is something which is selfevaluated meaning that the individual is the subject of that context, thus it is not context specific to the individual. Other's evaluations of a different individual's wellbeing can be context specific though. For example, a doctor's evaluation of wellbeing will be in a different context to a friend's 
evaluation. Environments such as school are concluded to be determinants of young people's wellbeing rather than contexts which wellbeing can change in.

\subsubsection{Basic needs and material goods}

Economic status can influence the experiences, quality of life and wellbeing an individual can have (Gardner \& Oswald, 2007). This was identified by both experts and adolescents. The importance of satisfying human wants however is arguably not important for wellbeing as wants are often concerned with short term, hedonic pleasure (Herath \& Ekanayake, 2017). In alignment with academic literature (Alexandrova, 2017), young people understood that money and material goods are important to enable survival however, excesses of money and material goods were agreed to have a limited, if not no, impact on wellbeing. During the ranking activity material goods (new clothes and xbox) and money were consistently ranked as least impactful on wellbeing (see Figure 3 above). Alexandrova (2017) also explains that the influence of money is relative to the individual and their overall income as individuals spend money within their means.

\section{Limitations}

During interviews one of the initial questions was 'What does the word wellbeing mean to you?'. Occasionally, participants from Group 2 stated they did not know. Interviewing these young people about wellbeing then posed a challenge as the idea was to understand their views and opinions about a topic which they disclosed they did not know about. The interviewer did not comment on this to avoid biasing the interviewees opinions, also to not influence their own openminded approach to the topic. Once these interviewees heard their peers discuss wellbeing, they contributed more during the interview. With the findings showing wellbeing was used interchangeably with happiness, this could explain the initial lack of understanding; alternatively, participants may have just been initially shy. This also infers not all young people are receiving education about wellbeing. A potential explanation for this is that because wellbeing is ambiguous, it makes it difficult to educate others about what it is and its importance. This provides support for the need of clarification regarding what young people's wellbeing is. Future studies should also adopt a focus group method when interviewing young people, as it enabled some participants to gain understanding on the topic and therefore, make meaningful contributions.

\section{Conclusion}

The need for a definition of adolescent's wellbeing has been highlighted in literature (Bharara et al, 2019). Findings have been organised into three themes, holism, positive feelings, external influences. Although there are similarities between expert's and adolescent's conceptualisations of wellbeing, there are some key differences. This supports the rationale for the creation of an explicit definition of young people's wellbeing. Individual differences within the same population must also be considered as they were discussed in relation to wellbeing in every interview. This is reflected in literature where some authors have used the term 'subjective wellbeing' (Goodman et al., 2018; Mansfield et al., 2018; Testoni, Mansfield \& Dolan., 2018; White et al., 2017; Rees et al., 2010; Diener et al., 1999) as an alternative to 'wellbeing'. All social research using human participants, including the measurement of health, can be criticised for subjectivity and individual differences (Bowling, 2017). This is not unique to wellbeing. The definition of 
wellbeing therefore needs to be open to individual differences which the two broad themes 'positive feelings' and 'external influences' accommodate, tackling wellbeing's ambiguity.

Adolescent's wellbeing is multi-faceted and influenced by both positive feelings, such as happiness and evaluation of health, and external influences, such as connections and judgements. Individual differences will influence the values placed on external influences of wellbeing. This makes defining a 'normal' level of wellbeing difficult (Dodge et al., 2012). In conclusion, adolescent's wellbeing is defined as:

A multifaceted perception of an interaction between an individual's positive feelings and external influences

This definition is broad to encapsulate individual differences, but sill sets a parameter for what wellbeing is. 'Perception' relates to what the individual perceives of themselves. The term 'interaction' has been chosen to show that both positive feelings and external influences impact and affect each other. External influences and positive feelings alone do not define wellbeing but contribute to it, the interaction between external influences and positive feelings define an individual's level of wellbeing. This interaction is continuous and how an individual perceives this interaction defines their level of wellbeing. An example within the context of this study is that the external influence 'social interaction' and the positive feeling 'determination' will both impact each other. If one is feeling determined, this may impact their social connection to others vice versa. The perception an individual has over this interaction defines their wellbeing. The proposed definition is based on adolescent's conceptualisations of wellbeing, supported by a sample of expert's conceptualisations. This definition should only be applied to the population of British adolescents aged 11 to 16 as this is where it was developed. Future research should consult with different populations to make a definition of wellbeing specific to the population.

\section{Acknowledgments}

With thanks to all those involved within the research and the schools and sports clubs who made it possible.

\section{Authors}

Ellie K. Gennings

University of Winchester

ellie.gennings@winchester.ac.uk

Hazel J. Brown

University of Winchester

Denise Hewlett

University of Winchester

\section{Publishing Timeline}

Received 20 October 2020

Revised version received 22 January 2021

Accepted 24 January 2021

Published 31 January 2021

\section{References}

Alexandrova, A. (2017). A Philosophy for the Science of Wellbeing. United States of America: Oxford University Press. https://doi.org/10.1093/oso/9780199300518.001.0001 
Andresen, S., Bradshaw, J., \& Kosher, H. (2019). Young children's perceptions of their lives and wellbeing. Child Indicators Research, 12(1), 1-7. https://doi.org/10.1007/s12187-018-9551-6

Bharara, G., Duncan, S., Jarden, A., \& Hinckson, E. (2019). A prototype analysis of New Zealand adolescents' conceptualizations of wellbeing. International Journal of Wellbeing, 9(4), 1-25. https://doi.org/10.5502/ijw.v9i4.975

Blanchflower, D. G., \& Oswald, A. J. (2008). Is wellbeing U-shaped over the life cycle? Social Science \& Medicine, 66(8), 1733-1749. https://doi.org/10.1016/j.socscimed.2008.01.030

Blaskova, L. J., \& McLellan, R. (2018). Young people's perceptions of wellbeing: The importance of peer relationships in Slovak schools. International Journal of School \& Educational Psychology, 6(4), 279-291. https://doi.org/10.1080/21683603.2017.1342579

Bourke, L., \& Geldens, P. (2007). What Does Wellbeing Mean? Perspectives of Wellbeing among Young People \& Youth Workers in Rural Victoria. Youth Studies Australia, 26(1), 41.

Bowling, A. (2014). Research methods in health: investigating health and health services: McGraw-Hill education (UK).

Bowling, A. (2017). Measuring health: a review of subjective health, wellbeing and quality of life measurement scales (Fourth ed.). Glasgow: Open University Press.

Boyko, C., Coulton, C., Sabbagh-Gomez, A., Cooper, R. (2017). The Little Book of Wellbeing: A Guide to Wellbeing in Urban Environments. Imagination Lancaster, 4-27.

Bradshaw, J., Hoelscher, P., \& Richardson, D. (2007). An index of child well-being in the European Union. Social Indicators Research, 80(1), 133-177. https://doi.org/10.1007/s11205-006-9024-z

Braun, V., \& Clarke, V. (2006). Using thematic analysis in psychology. Qualitative Research in Psychology, 3(2), 77-101. https://doi.org/10.1191/1478088706qp063oa

Brown, K. W., \& Ryan, R. M. (2003). The benefits of being present: Mindfulness and its role in psychological wellbeing. Journal of Personality and Social Psychology, 84(4), 822. https://doi.org/10.1037/0022-3514.84.4.822

Clarke, A., Friede, T., Putz, R., Ashdown, J., Martin, S., Blake, A., ... \& Stewart-Brown, S. (2011). WarwickEdinburgh Mental Wellbeing Scale (WEMWBS): Validated for teenage school students in England and Scotland. A mixed methods assessment. BMC Public Health, 11(1), 487. https://doi.org/10.1186/1471-2458-11-487

Courtin, E., \& Knapp, M. (2017). Social isolation, loneliness and health in old age: A scoping review. Health \& Social Care in the Community, 25(3), 799-812. https://doi.org/10.1111/hsc.12311

Deci, E. L., \& Ryan, R. M. (2008). Hedonia, eudaimonia, and wellbeing: An introduction. Journal of happiness studies, 9(1), 1-11. https://doi.org/10.1007/s10902-006-9018-1

Diener, E., \& Suh, E. (1997). Measuring quality of life: Economic, social, and subjective indicators. Social Indicators Research, 40(1-2), 189-216. https://doi.org/10.1023/A:1006859511756

Diener, E., Suh, E. M., Lucas, R. E., \& Smith, H. L. (1999). Subjective wellbeing: Three decades of progress. Psychological bulletin, 125(2), 276. https://doi.org/10.1037/0033-2909.125.2.276

Disabato, D., Goodman, F., \& Kashdan, T. B. (2019). A hierarchical framework of well-being. PsyArXiv, 168. https://doi.org/10.31234/osf.io/5rhqj

Dodge, R., Daly, A., Huyton, J., \& Sanders, L. (2012). The challenge of defining wellbeing. International Journal of Wellbeing, 2(3), 222-235. https://doi.org/10.5502/ijw.v2i3.4

Dunlop-Bennett, E., Bryant-Tokalau, J., \& Dowell, A. (2019). When you ask the fish: Child wellbeing through the eyes of Samoan children. International Journal of Wellbeing, 9(4), 97-120. https://doi.org/10.5502/ijw.v9i4.1005

Foley, K. R., Blackmore, A. M., Girdler, S., O’Donnell, M., Glauert, R., Llewellyn, G., \& Leonard, H. (2012). To feel belonged: The voices of children and youth with disabilities on the meaning of wellbeing. Child Indicators Research, 5(2), 375-391. https://doi.org/10.1007/s12187-011-9134-2

Gabhainn, S. N., \& Sixsmith, J. (2005). Children's understanding of Wellbeing. Stationery Office. https://doi.org/10.1037/e531242013-001

Gardner, J., \& Oswald, A. J. (2007). Money and mental wellbeing: A longitudinal study of medium-sized lottery wins. Journal of Health Economics, 26(1), 49-60. https://doi.org/10.1016/j.jhealeco.2006.08.004 
Gibson, F. (2007). Conducting focus groups with children and young people: strategies for success. Journal of Research in Nursing, 12(5), 473-483. https://doi.org/10.1177\%2F1744987107079791

Gillett-Swan, J. K. (2014). Investigating tween children's capacity to conceptualise the complex issue of wellbeing. Global Studies of Childhood, 4(2), 64-76. https://doi.org/10.2304/gsch.2014.4.2.64

Goodman, F. R., Disabato, D. J., Kashdan, T. B., \& Kauffman, S. B. (2018). Measuring wellbeing: A comparison of subjective wellbeing and PERMA. The Journal of Positive Psychology, 13(4), 321-332. https://doi.org/10.1080/17439760.2017.1388434

Headey, B., \& Wearing, A. (1992). Understanding happiness: A theory of subjective wellbeing. Melbourne: Longman Cheshire.

Herath, D. L., R. W. D. Ekanayake, A. (2017). Urban Resettlement in Colombo from a Wellbeing Perspective: Does Development-Forced Resettlement Lead to Improved Wellbeing? Journal of Refugee Studies, 30(4), 554-579. https://doi.org/10.1093/jrs/few043

Hone, L., Schofield, G., \& Jarden, A. (2015). Conceptualizations of wellbeing: Insights from a prototype analysis on New Zealand workers. New Zealand Journal of Human Resource Management, 15(2), 97118.S

Humberstone, B. (2015). Embodiment, nature and wellbeing. In Experiencing the outdoors (pp. 61-72). Springer. https://doi.org/10.1007/978-94-6209-944-9_6

Huppert, F. A., \& So, T. T. (2013). Flourishing across Europe: Application of a new conceptual framework for defining wellbeing. Social Indicators Research, 110(3), 837-861. https://doi.org/10.1007/s11205-0119966-7

Kelly, C. (2018). 'I Need the Sea and the Sea Needs Me': Symbiotic coastal policy narratives for human wellbeing and sustainability in the UK. Marine Policy, 97, 223-231. https://doi.org/10.1016/j.marpol.2018.03.023

Corey Lee M. Keyes. (1998). Social Well-Being. Social Psychology Quarterly, 61(2), 121-140. https://doi.org/10.2307/2787065

Lees, A., Payler, J., Ballinger, C., Lawrence, P., Faust, S. N., \& Meads, G. (2017). Positioning children's voice in clinical trials research: A new model for planning, collaboration, and reflection. Qualitative Health Research, 27(14), 2162-2176. https://doi.org/10.1177\%2F1049732317726760

Lunenburg, F. C. (2011). Goal-setting theory of motivation. International Journal of Management, Business, $\mathcal{E}$ Administration, 15(1), 1-6.

Liddle, I., \& Carter, G. F. (2015). Emotional and psychological wellbeing in children: the development and validation of the Stirling Children's Wellbeing Scale. Educational Psychology in Practice, 31(2), 174185. https://doi.org/10.1080/02667363.2015.1008409

Lijadi, A. A. (2018). Theoretical Foundations to outline Human Wellbeing: Metaanalytic Literature Review for defining Empowered Life Years. IIASA Working Paper. IIASA, Laxenburg, Austria: WP18-002

Lundy, L., McEvoy, L., \& Byrne, B. (2011). Working with Young Children as Co-Researchers: An Approach Informed by the United Nations Convention on the Rights of the Child. Early Education and Development, 22(5), 714-736. https://doi.org/10.1080/10409289.2011.596463

MacKenzie, S. B., Podsakoff, P. M., \& Podsakoff, N. P. (2011). Construct measurement and validation procedures in MIS and behavioral research: integrating new and existing techniques. MIS Quarterly, 35(2), 293-334. d https://doi.org/10.2307/23044045

Maguire, M., \& Delahunt, B. (2017). Doing a thematic analysis: A practical, step-by-step guide for learning and teaching scholars. AISHE-J: The All Ireland Journal of Teaching and Learning in Higher Education, 9(3), 1-14.

Manning-Morton, J. (2013). Exploring wellbeing in the early years: Thinking about wellbeing in early childhood. Open University Press.

Mansfield, L., Kay, T., Meads, C., John, A., Daykin, N., Duffy, G., . . Victor, C. (2018). A Systematic Review of Outdoor Recreation (in green space and blue space) for Families to Promote Subjective Wellbeing. What Works Centre for Wellbeing 1-62.

Maslow, A. H. (1943). A theory of human motivation. Psychological Review, 50(4), 370. https://doi.org/10.1037/h0054346 
Mata, A. D., van Dulmen, M. H., Schinka, K. C., Swahn, M. H., Bossarte, R. M., \& Flannery, D. J. (2012). Extracurricular activity involvement is associated with adolescent suicidality through school belongingness. Vulnerable Children Youth Studies, 7(4), 347-356. https://doi.org/10.1080/17450128.2012.708463

McLellan, R., \& Steward, S. (2015). Measuring children and young people's wellbeing in the school context. Cambridge Journal of Education, 45(3), 307-332. https://doi.org/10.1080/0305764X.2014.889659

Navarro, D., Montserrat, C., Malo, S., González, M., Casas, F., \& Crous, G. (2017). Subjective well-being: what do adolescents say? Child \& Family Social Work, 22(1), 175-184. https://doi.org/10.1111/cfs.12215

NHS Digital. (2018). Mental Health of Children and Young People in England, 2017. [online] Available: https://files.digital.nhs.uk/95/AC12EC/MHCYP\%202017\%20Multiple\%20Conditions.pdf.

Podsakoff, P. M., MacKenzie, S. B., \& Podsakoff, N. P. (2016). Recommendations for creating better concept definitions in the organizational, behavioral, and social sciences. Organizational Research Methods, 19(2), 159-203. https://doi.org/10.1177/1094428115624965

Pouw, N., \& McGregor, A. (2014). An Economics of Wellbeing: What Would Economics Look Like if it were Focused on Human Wellbeing? IDS Working Papers, 2014(436), 1-27. https://doi.org/10.1111/j.2040-0209.2014.00436.x

Povey, R. (2015). The welfare economics of infectious happiness. Economics Letters, 133, 1-3. https://doi.org/10.1016/j.econlet.2015.05.006

Putnam, R. D. (2001). Bowling alone: The collapse and revival of American community: Simon and Schuster. https://doi.org/10.1145/358916.361990

Rees, G., Goswami, H., \& Bradshaw, J. (2010). Developing an index of children's subjective wellbeing in England: Children's Society.

Ryan, R. M., \& Deci, E. L. (2001). On happiness and human potentials: A review of research on hedonic and eudaimonic wellbeing. Annual Review of Psychology, 52(1), 141-166. https://doi.org/10.1146/annurev.psych.52.1.141

Ryff, C. D., \& Keyes, C. L. (1995). The structure of psychological wellbeing revisited. Journal of Personality Social Psychology, 69(4), 719. https://doi.org/10.1037/0022-3514.69.4.719

Seligman, M. E. (2004). Authentic happiness: Using the new positive psychology to realize your potential for lasting fulfillment. Simon and Schuster.

Seligman, M. E. (2012). Flourish: A visionary new understanding of happiness and wellbeing: Simon and Schuster.

Shoshani, A. (2019). Young children's character strengths and emotional wellbeing: development of the Character Strengths Inventory for Early Childhood (CSI-EC). The Journal of Positive Psychology, 14(1), 86-102. https://doi.org/10.1080/17439760.2018.1424925

Smith, T. S. J., \& Reid, L. (2017). Which 'being' in wellbeing? Ontology, wellness and the geographies of happiness. Progress in Human Geography, 42(6), 807-829. https://doi.org/10.1177/0309132517717100

Spadaro, D., Robinson, L., \& Smith, L. (1980). Assessing Readability of Patient Information Materials. American journal of hospital pharmacy, 37, 215-221. https://doi.org/10.1093/ajhp/37.2.215

Spence, A., Powell, M., Self, A. (2011). Developing a Framework for Understanding and Measuring National Wellbing. Office for National Statistics, 2-8.

Stevens, S., \& Jarden, A. (2019). The importance of child wellbeing. International Journal of Wellbeing, 9(4). https://doi.org/10.5502/ijw.v9i4.1011

Tabor, D., \& Stockley, L. (2018). Personal Wellbeing in the UK, with Analysis by Country. Office for National Statistics., 1-13.

Tabor, D., \& Yull, J. (2018). Personal Wellbeing in the UK: July 2017 to June 2018. Office for National Statistics. 1-12.

Tennant, R., Hiller, L., Fishwick, R., Platt, S., Joseph, S., Weich, S., . . Stewart-Brown, S. (2007). The Warwick-Edinburgh mental wellbeing scale (WEMWBS): development and UK validation. Health and Quality of life Outcomes, 5(1), 63. https://doi.org/10.1186/1477-7525-5-63

Testoni, S., Mansfield, L., \& Dolan, P. (2018). Defining and measuring subjective wellbeing for sport policy. International Journal of Sport Policy and Politics, 10(4), 815-827. https://doi.org/10.1080/19406940.2018.1518253 
Thomas, N., Graham, A., Powell, M. A., \& Fitzgerald, R. (2016). Conceptualisations of children's wellbeing at school: The contribution of recognition theory. Childhood, 23(4), 506-520. https://doi.org/10.1177/0907568215622802

Tudor, K. (1996). Mental Health Promotion: Paradigms and Practice. London: Routledge.

United Nations. (2019). Goal 3: Ensure healthy lives and promote wellbeing for all at all ages. [online]. Available: https://www.un.org/sustainabledevelopment/health/

Waterman, A. S., Schwartz, S. J., Zamboanga, B. L., Ravert, R. D., Williams, M. K., Bede Agocha, V., .. . Brent Donnellan, M. (2010). The Questionnaire for Eudaimonic Wellbeing: Psychometric properties, demographic comparisons, and evidence of validity. The Journal of Positive Psychology, 5(1), 41-61. https://doi.org/10.1080/17439760903435208

White, M. P., Pahl, S., Wheeler, B. W., Depledge, M. H., \& Fleming, L. E. (2017). Natural environments and subjective wellbeing: Different types of exposure are associated with different aspects of wellbeing. Health \& Place, 45, 77-84. https://doi.org/10.1016/j.healthplace.2017.03.008 